\title{
In Silico Analysis and Characterization of Differentially Expressed Genes to Distinguish Glioma Stem Cells from Normal Neural Stem Cells
}

Urja Parekh*1,2, Mohit Mazumder², Harpreet Kaur², Elia Brodsky²

${ }^{1}$ Deparment of Biological Science, Sunandan Divatia School of Science, Narsee Monjee Institute of Management Studies, India

2 Pine Biotech, USA

\section{Emails of Authors:}

Urja Parekh: urjaparekh@gmail.com

Mohit Mazumder: mohit@pine.bio

Harpreet Kaur: support@pine.bio; hks04180@gmail.com

Elia Brodsky: elia@pine.bio

*Author for correspondence: urjaparekh@gmail.com

\begin{abstract}
Glioblastoma multiforme (GBM) is a heterogeneous, invasive primary brain tumor that develops chemoresistance post therapy. Theories regarding the aetiology of GBM focus on transformation of normal neural stem cells (NSCs) to a cancerous phenotype or tumorigenesis driven via glioma stem cells (GSCs). Comparative RNA-Seq analysis of GSCs and NSCs can provide a better understanding of the origin of GBM. Thus, in the current study, we performed various bioinformatics analyses on transcriptional profiles of a total 40 RNA-seq samples including 20 NSC and 20 GSC, that were obtained from the NCBI-SRA (SRP200400). First, differential gene expression (DGE) analysis using DESeq2 revealed 348 significantly differentially expressed genes between GSCs and NSCs (padj. value $<0.05$, log2fold change $\geq 3.0$ (for GSCs) and $\leq-3.0$ (for NSCs)) with 192 upregulated and 156 downregulated genes in GSCs in comparison to NSCs. Subsequently, exploratory data analysis using principal component analysis (PCA) based on key significant genes depicted the clear separation between both the groups. Further, Hierarchical clustering confirmed the distinct clusters of GSC and NSC samples. Eventually, the biological enrichment analysis of the significant genes showed their enrichment in tumorigenesis pathways such as Wnt-signalling, VEGF-signalling and TGF- $\beta$-signalling pathways. Conclusively, our study depicted significant differences in the gene expression patterns between NSCs and GSCs. Besides,
\end{abstract}


we also identified novel genes and genes previously unassociated with gliomagenesis that may prove to be valuable in establishing diagnostic, prognostic biomarkers and therapeutic targets for GBM.

Keywords: RNA-Seq Analysis, DGE, Machine Learning, Glioblastoma multiforme, Cancer stem cells

\section{Introduction}

Glioblastoma multiforme (GBM), a grade IV glioma that accounts for over $60 \%$ of all primary brain tumors, is associated with very poor prognosis and an overall survival period of a mere 15 months post-surgery, radiotherapy and temozolomide (TMZ) chemotherapy (Stupp et al., 2009). It is an aggressive and recurring cancer with a median relapse rate of 7 months (Weller et al., 2009). Despite several advances in therapies over the past few years, GBM remains one of the most devastating and difficult brain cancers to treat owing to its interpatient and intratumoral heterogeneity, subsequent resistance to chemotherapy, lack of significant therapeutic biomarkers and inaccessibility of the tumors, for therapeutic intervention, based on their locations in the brain (Holland, 2000; Weller et al., 2009).

Glioblastoma is termed multiforme because its phenotypic and genetic heterogeneity imparts complexity to this particular cancer. GBM tumors have been classified into mesenchymal, classical, proneural/IDH mutant and proneural/RTK mutant variants depending on their molecular signatures (Chen et al., 2017). 90\% of GBMs occur de novo in elderly patients, while secondary GBMs arise from low grade astrocytomas in younger patients. Known genetic hallmarks of primary GBM include gene mutation and amplification of epidermal growth factor receptor (EGFR), overexpression of mouse double minute 2 (MDM2), deletion of p16 and loss of heterozygosity $(\mathrm{LOH})$ of chromosome 10q holding phosphatase and tensin homolog (PTEN) and TERT promoter mutation. In contrast, secondary GBM have different genetic signatures such as over expression of platelet-derived growth factor $\mathrm{A}$, and platelet-derived growth factor receptor alpha (PDGFA/PDGFRa), retinoblastoma (RB), LOH of 19q and mutations of IDH1/2, TP53 and ATRX (Hanif et al., 2017). Further, single-cell RNA-Seq studies have revealed that different cell types with varying genetic patterns may be present within a tumor, which may be helpful in determining the prognosis of the tumor. Cancer stem cells account for one such small population 
of cells and are predicted to drive tumorigenesis and impart chemoresistance in GBM (Couturier et al., 2020).

Despite several efforts made by researchers to understand the cytogenetic aspects of these tumors, the etiology of it still remains largely unknown. Two hypotheses have been postulated that suggest its origin. The cancer stem cell theory purports that GBM originates from cancer stem cells (CSCs) that are responsible for self-renewal, development, propagation and recurrence of the tumor. The other theory states that GBM arises via transformation of normal neural stem cells after accumulation of several mutations in common neural stem cell marker genes (Couturier et al., 2020; Yao et al., 2018). This concept is rather complex since GSCs may share certain genetic similarities with NSCs, however, the molecular differences may underpin the malignant growth potential of the tumor. Thus, it is important to understand the differences in gene expression between normal neural stem cells (NSCs) and Glioblastoma Stem Cells (GSCs) to be able to better determine the cellular origin of the tumor.

In this study, we performed RNA-Seq analysis using NSC and GSC samples to understand the differences in their gene expression profiles, understand the origin of GBM, and identify potential biomarkers that may allow for selective targeting of CSCs while sparing normal NSCs via precision medicine.

\section{Methods}

\section{Acquisition of RNA-Seq Data}

A thorough search of the Gene Expression Omnibus (GEO) Database was performed to obtain the ideal dataset for the study. The GSE132172 (associated Sequence Retrieval Archive (SRA) Study: SRP200400) dataset was selected (Zhao et al., 2019). This dataset consisted of RNA-Seq data retrieved from CB660 normal neural stem cell lines and GliNS2 glioblastoma stem cell lines. Of the 188 samples present on the associated SRA Run Selector, 20 samples of NSCs (SRR9200813 to SRR9200832) and 20 samples of GSCs (SRR9200895 to SRR9200914) were selected and downloaded as an SRA Run Table.

\section{RNA-Seq Data Analysis}

PCR clean and Trimmomatic algorithms were used to remove adapter sequence and low quality sequence data, mapping on genome and junctions was done via TopHat2, isoform construction via 
cufflinks, Gene transfer format (GTF) processing via cuffmerge, mapping on transcripts via Bowtie2-t and the final gene expression values were obtained using RSEM algorithm as RsemExpTable in Fragments Per Kilobase of transcript per Million mapped reads (FPKM) units (figure 1). The gene expression data was log transformed and quantile normalized for further analysis.

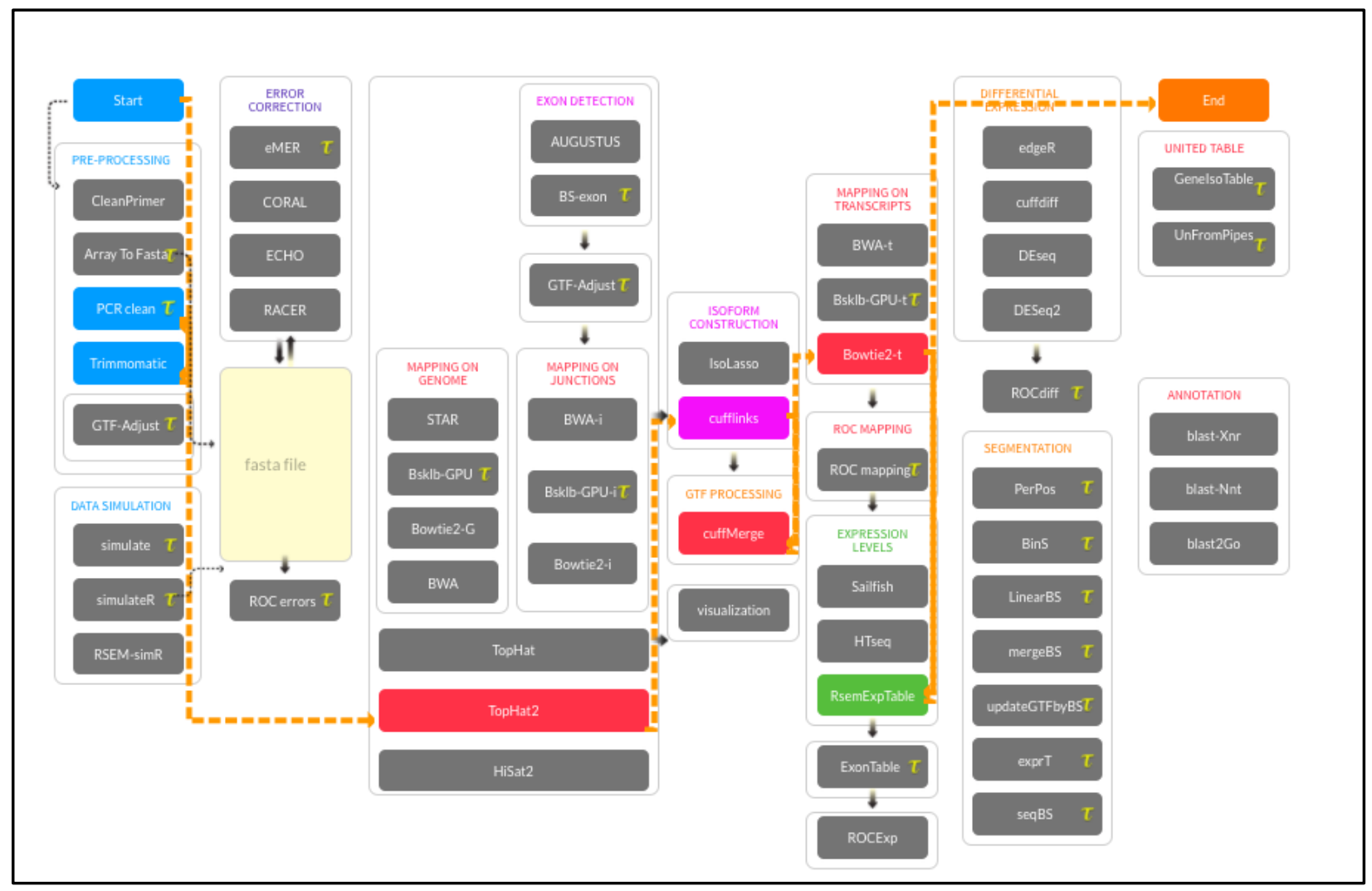

Figure 1. Screenshot of RNA-Seq Pipeline (Tuxedo Protocol).

\section{Downstream Data Analysis}

The 40 samples were clustered as per their gene expression profiles using Principal Component Analysis and Hierarchical Clustering (distance: Euclidean, linkage: ward.D2). Differential gene expression was performed using the DESeq2 pipeline to derive significantly expressed genes in GSC and NSC samples (figure 2). The differential gene expression data was then filtered and extracted if the threshold $=$ TRUE, p-adjusted value was $<0.05$ and $\log _{2}$ fold change value for GSCs was $\geq 3.0$ (for GSCs) and $\leq-3.0$ (for NSCs). Top 25 most highly expressed genes from each type of stem cell sample was further filtered and a heat map and dendrogram was generated to depict comparison of gene expression profiles in each type of sample. 


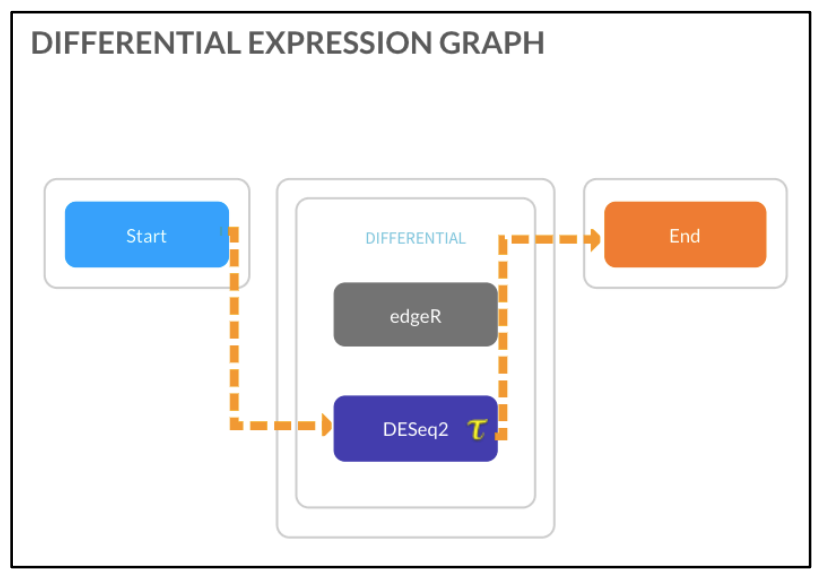

Figure 2. Screenshot of differential gene expression analysis using DeSeq2 Pipeline.

\section{Gene Enrichment Analysis}

To understand the biological implication of the significant genes obtained from differential gene expression analysis, the gene lists were uploaded on the Database for Annotation, Visualization and Integrated Discovery (DAVID) v6.8 tool. Kyoto Encyclopedia of Genes and Genomes (KEGG) was also used for pathway analysis. Literature review for the top 50 most significant differentially expressed genes (which include top 25 upregulated and top 25 down regulated genes in GSCs vs. NSCs) was performed via Google Scholar, National Center for Biotechnology Information (NCBI) PubMed and GeneCards ${ }^{\circledR}$, to understand their functions in a normal physiological condition and in gliomagenesis.

\section{Results}

Gene expression data in FPKM units for a total of 27,385 genes was obtained in the RSemExp table after the RNA-Seq Pipeline (Tuxedo Protocol) was run. Post quantile normalization and logscale transformation, PCA plot was generated which revealed separate clustering of GSC and NSC samples with a principal component 1 (PC1) of $10.31 \%$ and PC2 of $8.9 \%$ (supplementary figure 1a). A single outlier (SRR9200898_PE), which was a glioma stem cell sample, was revealed. Thus, another PCA plot was generated without the outlier. A PC1 of $88.03 \%$ and a PC2 of $2.13 \%$ was obtained with this plot (supplementary figure 1b). To further confirm these findings, hierarchical clustering was performed that revealed NSC samples (SRR9200813 to SRR9200832) and GSC samples (SRR9200895 to SRR9200897 and SRR9200899 to SRR9200914) clustered separately. 
The outlier GSC sample (SRR9200898_PE) lay between the two clusters (supplementary figure 2).

Further analysis done via differential gene expression revealed 12,437 (45.42\% of the total genes) differentially expressed genes between NSC and GSC samples. This data was filtered and a total of 951 significantly expressed genes (7.64\% of all differentially expressed genes) with a threshold $=$ TRUE and $p$-adjusted value $\leq 0.05$ was obtained. A volcano plot was generated to depict these significantly differentially expressed genes between NSCs and GSCs (figure 3). Further filtering was performed to narrow down the most highly differentially expressed genes between NSCs and GSCs. A threshold of $\geq 3.0$ (for GSCs) and $\leq-3.0$ (for NSCs) was set for the $\log _{2}$ fold change value. Thus, we were left with 348 significantly differentially expressed genes. Among them, 192 genes were found to be upregulated and 156 to be downregulated in GSCs in comparison to NSCs. Further, we selected top 50 significantly differentially expressed genes including top 25 upregulated and top 25 downregulated genes in GSCs vs. NSCs (Table 1)

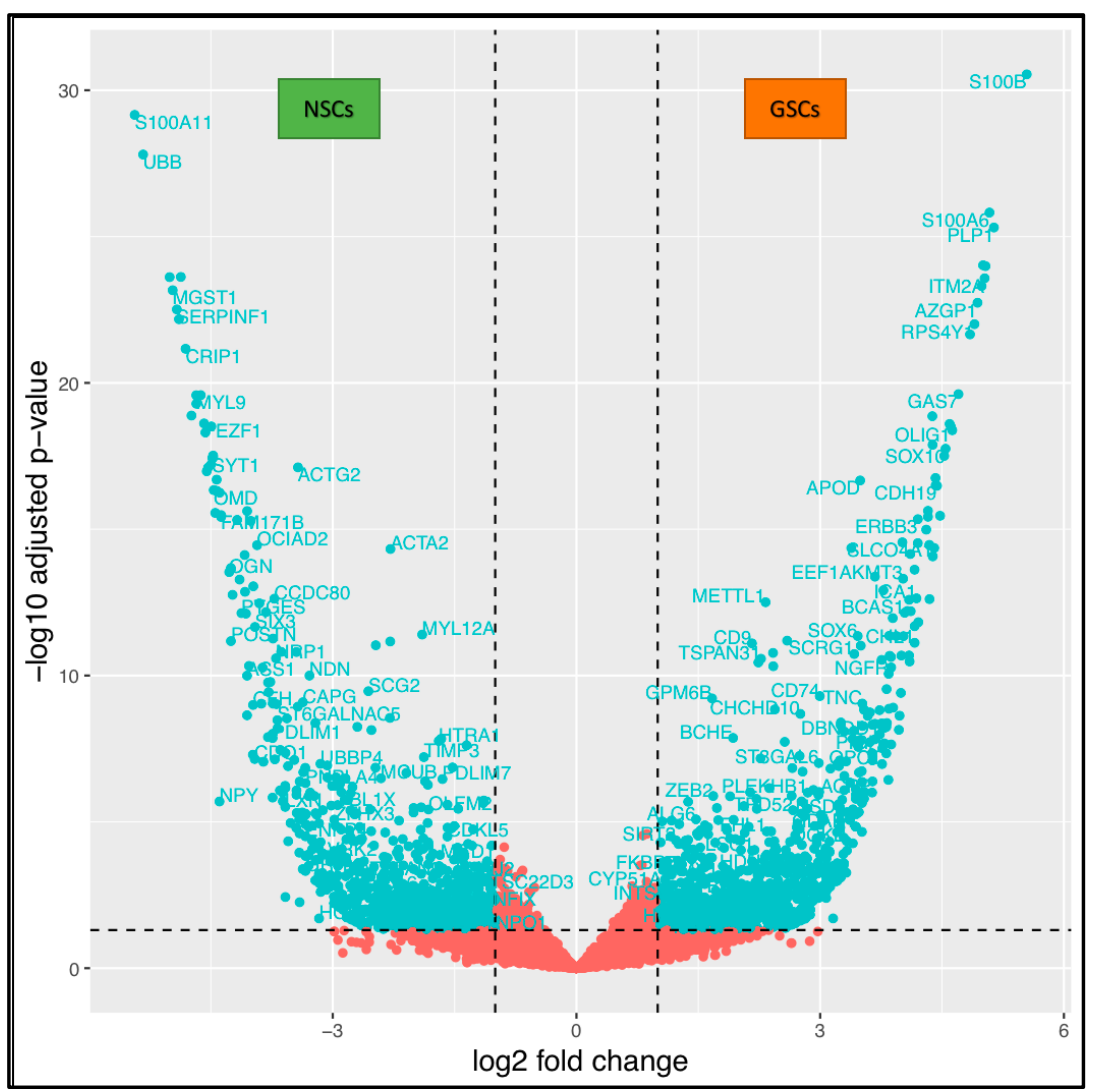

Figure 3. Volcano plot of differentially expressed genes between GSCs and NSCs 
Table 1: Top 50 differentially expressed genes in GSCs vs NSCs

\begin{tabular}{|c|c|c|c|c|c|}
\hline \multicolumn{3}{|c|}{ Upregulated Genes } & \multicolumn{3}{|c|}{ Downregulated Genes } \\
\hline $\begin{array}{l}\text { ENSEMBL } \\
\text { Gene ID }\end{array}$ & Entrez Gene ID & $\begin{array}{l}\log _{2} \text { fold } \\
\text { change }\end{array}$ & $\begin{array}{l}\text { ENSEMBL } \\
\text { Gene ID }\end{array}$ & $\begin{array}{l}\text { Entrez } \\
\text { Gene ID }\end{array}$ & $\begin{array}{l}\log _{2} \text { fold } \\
\text { change }\end{array}$ \\
\hline $\begin{array}{l}\text { ENSG00000160 } \\
307.8\end{array}$ & S100B & $\begin{array}{l}5.542941 \\
4\end{array}$ & $\begin{array}{l}\text { ENSG000001 } \\
63191.5\end{array}$ & S100A11 & -5.437646 \\
\hline $\begin{array}{l}\text { ENSG00000197 } \\
956.8\end{array}$ & PLP1 & $\begin{array}{l}5.084731 \\
68\end{array}$ & $\begin{array}{l}\text { ENSG000001 } \\
70315.12\end{array}$ & UBB & -5.334275 \\
\hline $\begin{array}{l}\text { ENSG00000189 } \\
058.7\end{array}$ & S100A6 & $\begin{array}{l}3.492410 \\
54\end{array}$ & $\begin{array}{l}\text { XLOC_02925 } \\
2\end{array}$ & unknown & -5.0073837 \\
\hline $\begin{array}{l}\text { ENSG00000135 } \\
919.11\end{array}$ & PMP2 & $\begin{array}{l}3.382881 \\
44\end{array}$ & $\begin{array}{l}\text { ENSG000000 } \\
08394.11\end{array}$ & MGST1 & -4.9702519 \\
\hline $\begin{array}{l}\text { ENSG00000261 } \\
857.5\end{array}$ & ITM2A & $\begin{array}{l}4.380766 \\
97\end{array}$ & $\begin{array}{l}\text { ENSG000001 } \\
32386.9\end{array}$ & SERPINF1 & -4.9191335 \\
\hline $\begin{array}{l}\text { ENSG00000229 } \\
344.1\end{array}$ & GPNMB & $\begin{array}{l}3.674091 \\
69\end{array}$ & $\begin{array}{l}\text { ENSG000001 } \\
52583.11\end{array}$ & SPARCL1 & -4.8928578 \\
\hline $\begin{array}{l}\text { ENSG00000136 } \\
235.14\end{array}$ & $\begin{array}{l}\text { THY1/ } \\
\text { CD90 }\end{array}$ & $\begin{array}{l}5.005325 \\
03\end{array}$ & $\begin{array}{l}\text { ENSG000001 } \\
97614.9\end{array}$ & MFAP5 & -4.8696255 \\
\hline $\begin{array}{l}\text { ENSG00000123 } \\
560.12\end{array}$ & AZGP1 & $\begin{array}{l}5.138722 \\
36\end{array}$ & $\begin{array}{l}\text { ENSG000002 } \\
13145.8\end{array}$ & CRIP1 & -4.8111644 \\
\hline $\begin{array}{l}\text { ENSG00000147 } \\
588.6\end{array}$ & RPS4Y1 & $\begin{array}{l}5.035382 \\
5\end{array}$ & $\begin{array}{l}\text { ENSG000001 } \\
39329.4\end{array}$ & LUM & -4.7388415 \\
\hline $\begin{array}{l}\text { ENSG00000078 } \\
596.9\end{array}$ & MATN2 & $\begin{array}{l}5.024294 \\
05\end{array}$ & $\begin{array}{l}\text { ENSG000001 } \\
01335.8\end{array}$ & MYL9 & -4.6796897 \\
\hline
\end{tabular}




\begin{tabular}{|c|c|c|c|c|c|}
\hline $\begin{array}{l}\text { ENSG00000154 } \\
096.12\end{array}$ & GAS7 & $\begin{array}{l}4.986803 \\
54\end{array}$ & $\begin{array}{l}\text { ENSG000001 } \\
09113.16\end{array}$ & RAB34 & -4.6787092 \\
\hline $\begin{array}{l}\text { ENSG00000160 } \\
862.11\end{array}$ & KRBOX1 & $\begin{array}{l}4.936816 \\
08\end{array}$ & $\begin{array}{l}\text { ENSG000001 } \\
98467.12\end{array}$ & TPM2 & -4.6243914 \\
\hline $\begin{array}{l}\text { ENSG00000129 } \\
824.14\end{array}$ & OLIG1 & $\begin{array}{l}4.899062 \\
93\end{array}$ & $\begin{array}{l}\text { ENSG000001 } \\
28610.10\end{array}$ & FEZF1 & -4.5842385 \\
\hline $\begin{array}{l}\text { ENSG00000110 } \\
693.14\end{array}$ & PRR34-AS1 & $\begin{array}{l}3.462027 \\
45\end{array}$ & $\begin{array}{l}\text { ENSG000001 } \\
38829.9\end{array}$ & FBN2 & -4.5675219 \\
\hline $\begin{array}{l}\text { ENSG00000164 } \\
434.10\end{array}$ & SOX10 & $\begin{array}{l}3.778498 \\
68\end{array}$ & $\begin{array}{l}\text { ENSG000002 } \\
25383.5\end{array}$ & SFTA1P & -4.5507508 \\
\hline $\begin{array}{l}\text { ENSG00000154 } \\
553.12\end{array}$ & Unknown & $\begin{array}{l}4.383849 \\
76\end{array}$ & $\begin{array}{l}\text { ENSG000001 } \\
31435.11\end{array}$ & PDLIM4 & -4.5340762 \\
\hline $\begin{array}{l}\text { ENSG00000164 } \\
106.6\end{array}$ & TSPAN7 & $\begin{array}{l}3.419188 \\
91\end{array}$ & $\begin{array}{l}\text { ENSG000001 } \\
04723.19\end{array}$ & TUSC3 & -4.4994617 \\
\hline $\begin{array}{l}\text { ENSG00000132 } \\
561.12\end{array}$ & CDH9 & $\begin{array}{l}4.844441 \\
81\end{array}$ & $\begin{array}{l}\text { ENSG000001 } \\
29038.14\end{array}$ & LOXL1 & -4.4942203 \\
\hline $\begin{array}{l}\text { ENSG00000123 } \\
610.4\end{array}$ & MT1F & $\begin{array}{l}4.011633 \\
08\end{array}$ & $\begin{array}{l}\text { ENSG000000 } \\
67715.12\end{array}$ & SYT1 & -4.4821866 \\
\hline $\begin{array}{l}\text { ENSG00000007 } \\
237.17\end{array}$ & NTRK2 & $\begin{array}{l}4.702249 \\
23\end{array}$ & $\begin{array}{l}\text { ENSG000001 } \\
05971.13\end{array}$ & CAV2 & -4.4721796 \\
\hline $\begin{array}{l}\text { ENSG00000255 } \\
737.2\end{array}$ & FCRLA & $\begin{array}{l}3.499985 \\
67\end{array}$ & $\begin{array}{l}\text { ENSG000001 } \\
37962.11\end{array}$ & $\begin{array}{l}\text { ARHGAP2 } \\
9\end{array}$ & -4.4720021 \\
\hline $\begin{array}{l}\text { ENSG00000240 } \\
747.6\end{array}$ & SLCO4A1 & $\begin{array}{l}4.625379 \\
67\end{array}$ & $\begin{array}{l}\text { ENSG000001 } \\
27083.7\end{array}$ & OMD & -4.4647095 \\
\hline
\end{tabular}




\begin{tabular}{|c|c|c|c|c|c|}
\hline $\begin{array}{l}\text { ENSG00000184 } \\
221.11\end{array}$ & PDLIM3 & $\begin{array}{l}4.609997 \\
85\end{array}$ & $\begin{array}{l}\text { XLOC_01200 } \\
3\end{array}$ & Proneural & -4.4462352 \\
\hline $\begin{array}{l}\text { ENSG00000241 } \\
990.4\end{array}$ & MIA & $\begin{array}{l}4.593370 \\
58\end{array}$ & $\begin{array}{l}\text { ENSG000001 } \\
46411.5\end{array}$ & SLC2A12 & -4.4290885 \\
\hline $\begin{array}{l}\text { ENSG00000136 } \\
999.4\end{array}$ & LY96 & $\begin{array}{l}4.109256 \\
83\end{array}$ & $\begin{array}{l}\text { XLOC_04736 } \\
7\end{array}$ & $\begin{array}{l}\mathrm{p} 53- \\
\text { regulated } \\
\text { lncRNAs }\end{array}$ & -4.4287433 \\
\hline
\end{tabular}

Next, to determine the distinguishable potential of these top 50 significantly differentially expressed genes, we generated the PCA plots with only these significant genes with the outlier (Figure 4a) and without the outlier (Figure 4b). Subsequently, in the heatmap (Figure 5), we visualized the differential expression pattern of these genes among two types of samples, i.e. GSCs vs NSCs.

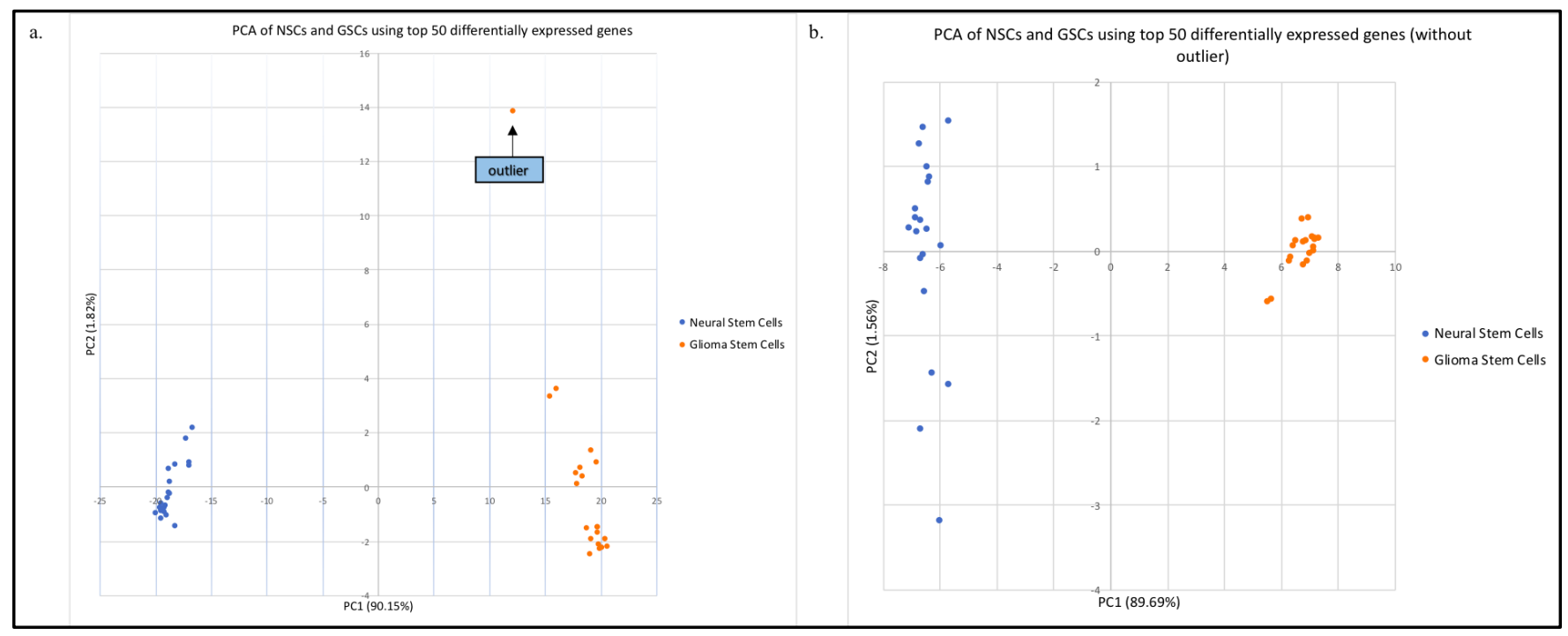

Figure 4. Exploratory data analysis using PCA based on the top 50 significantly differentially expressed genes between NSCs and GSCs. (a). PCA plot for all GSC and NSC samples, (b) PCA plot for GSC and NSC samples after removal of outlier. 


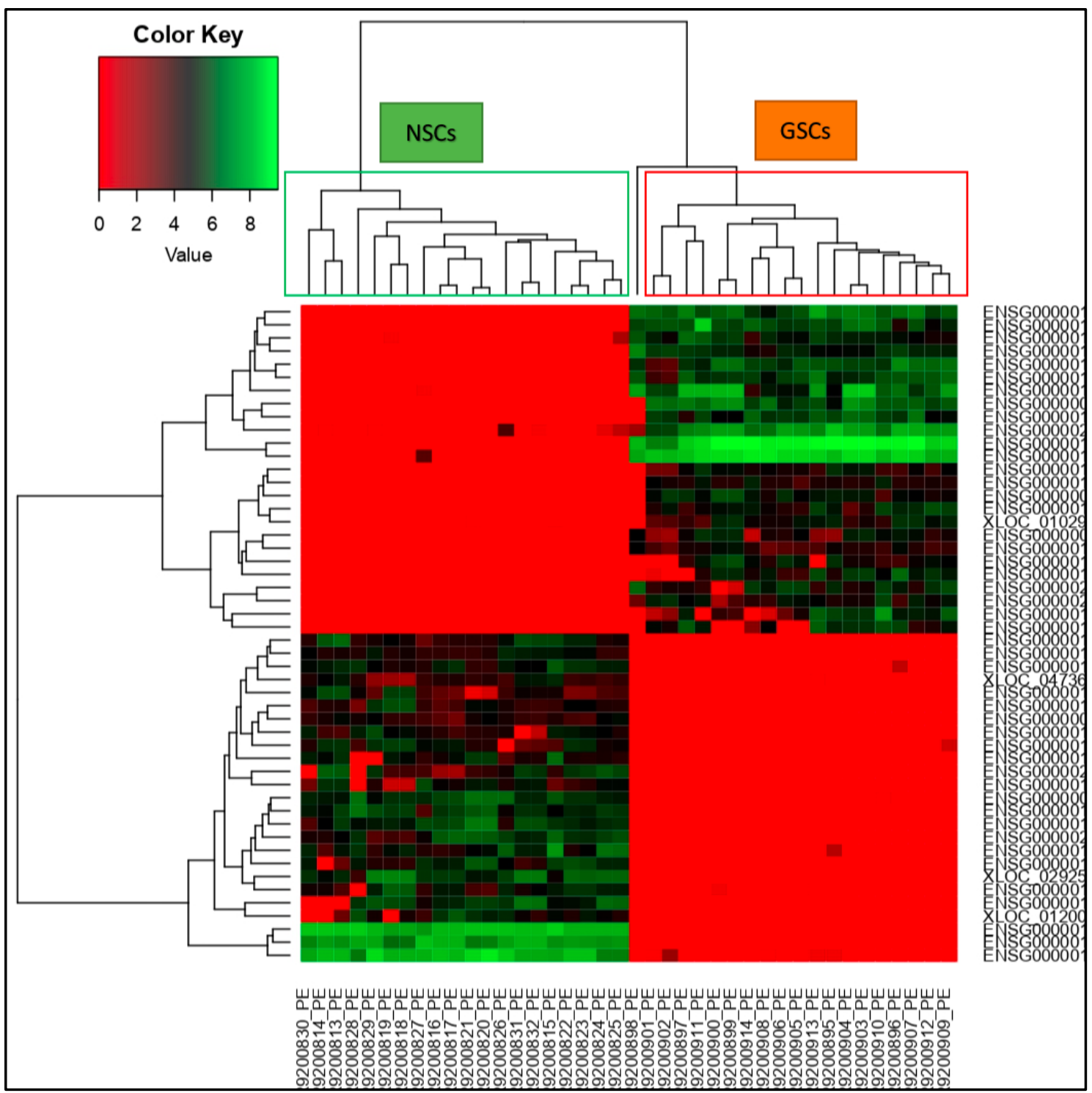

Figure 5. Heat map representing the expression pattern of the top 50 differentially expressed genes expressed genes between NSCs and GSCs.

Finally, we re-performed H-Clustering with the top 50 selected genes (figure 6). The GSC and NSC samples clustered separately, with the outlier sample branching in between the two clusters. 


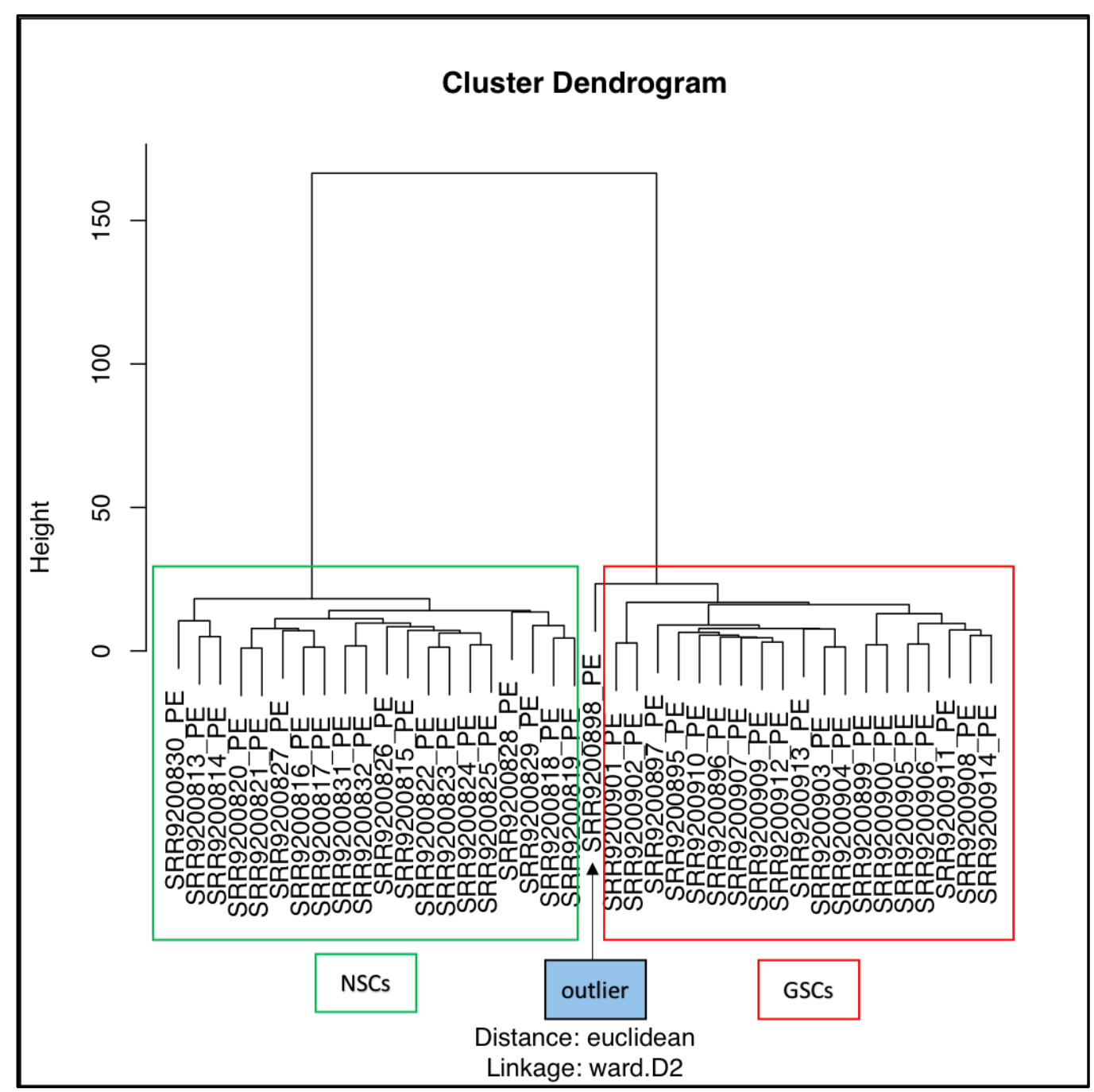

Figure 6. Dendrogram generated by Hierarchical clustering based on top 50 significantly differentially expressed genes depicting the distinct clusters of GSCs and NSCs samples.

\section{Gene Enrichment analysis}

The gene list for NSC containing 156 genes and for GSC containing 192 genes was uploaded on DAVID and functional annotation and clustering was performed.

Top hits with the NSC gene list indicated involvement in diseases such as Alzheimer's Disease, respiratory function tests, Tobacco Use Disorder, body weight, bone mineral density, macular degeneration, alcoholism, etc. Top hits for keyword annotations included extracellular matrix, secreted, glycoprotein, signal, calcium, disulphide bond, disease mutation, membrane and transmembrane. Top hits for sequence features included signal peptide, glycosylation (N-linked), Leucine Rich Repeats (LRR 6), EGF-like 6, LRR 5, LRR 1, LRR 2, LRR 7, LRR 4, disulphide 
bond, topological domain (cytoplasmic). Functional clustering (medium stringency) showed 27 clusters with 137 DAVID IDs with top three clusters involved in extracellular matrix, glycoprotein and LRRs and having enrichment scores of 5.99, 4.95 and 2.05, respectively.

Similarly, the gene list for GSC containing 192 genes was also uploaded on DAVID and top hits for diseases included Schizophrenia, Attention deficit hyperactivity disorder (ADHD), tobacco use disorder, depression, body height, body weight, autism, myocardial Infarction. Top hits for keyword annotations included disulphide bond, glycoprotein, signal, MHC-II, cell adhesion, cell membrane, alternative splicing, polymorphism, transmembrane. Top hits for sequence features included glycosylation (N-linked), signal peptide, disulphide bond, topological domain (extracellular and cytoplasmic), transmembrane, splice variant, sequence variant. Functional clustering (medium stringency) showed 27 clusters with 163 DAVID IDs with top three clusters involved in glycoprotein disulphide bonds, melanocyte differentiation metallothionein domain and having enrichment scores of 6.17, 2.35 and 2.15, respectively.

KEGG Pathway analysis depicted genes such as Ankyrin, $\alpha 2 \beta 1$, Lumican, Wnt, $\alpha 5 \beta 1$, SDC-4 and Caveolin from the list that were involved in various tumorigenesis pathways. Other genes such as PVRL3, PVRL2, NCAM, L1CAM, IGSF4, CDH3 and NEO1, enriched in the neural system, were also depicted. ECM Receptor Interaction genes such as Fibronectin, Collagen, Laminin, Tenascin, $\alpha \mathrm{V}, \beta 8$, Thrombospondin (THBS) and Osteopontin (OPN), were observed in the pathway analysis. Genes such as FAK, PAK, RasGAP, Ephrin A, Ephrin B, Robo1, Robo3, ERK, Cofilin, GSK3 $\beta$, Plexin B involved in axon guidance pathways, and genes such as PLC $\beta$, PLC $\gamma$, RTK, PMCA involved in calcium signaling pathways were also enriched in the gene lists (figure 7). 


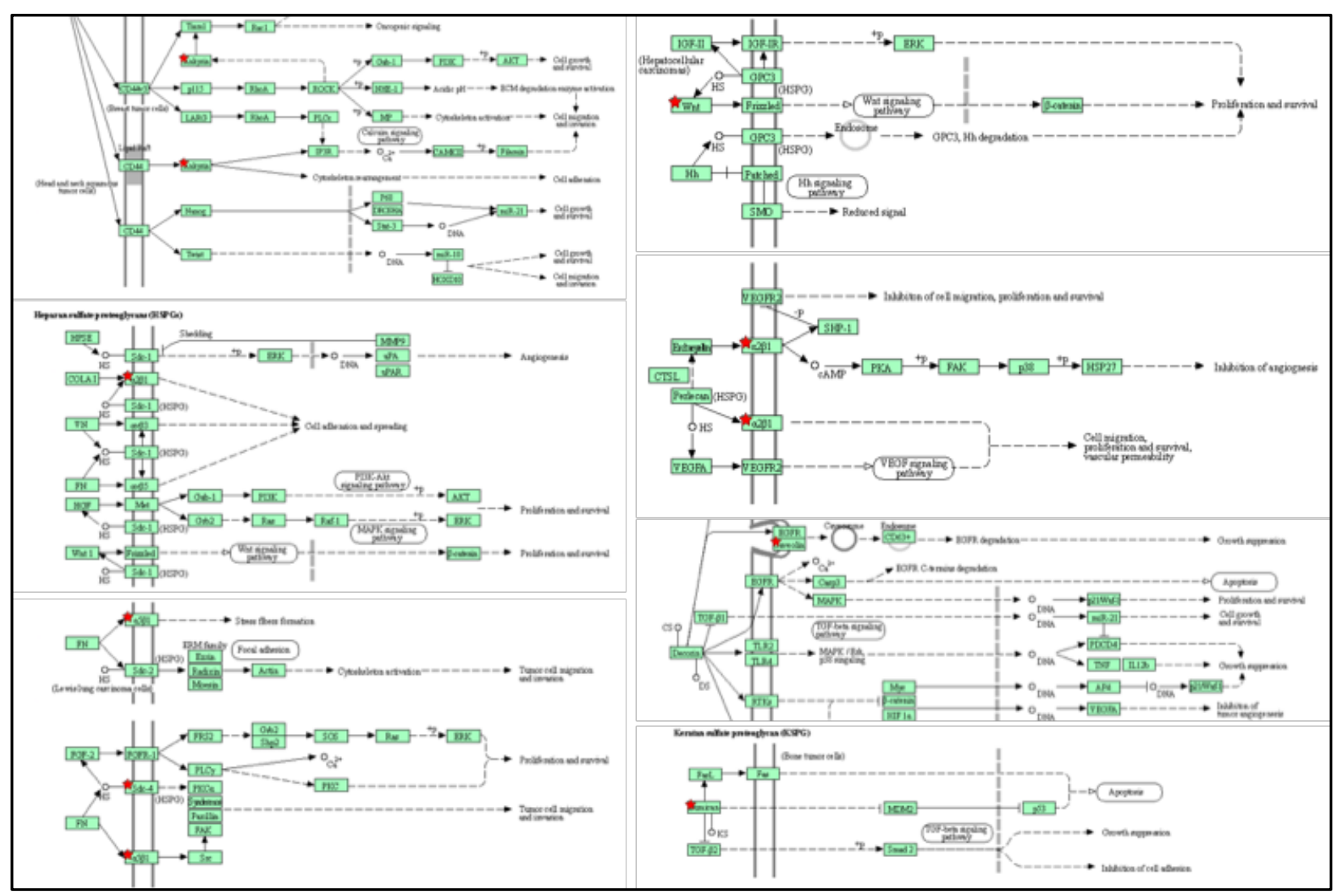

Figure 7: Pathway analysis of significant genes in GSC and NSC samples.

The detailed information regarding the roles and functions of the top 25 highly upregulated and 25 highly downregulated genes in GSCs and NSCs, within normal pathophysiology and gliomagenesis is tabulated in Tables (see Supplementary tables S1 and S2). Upregulated genes such as S100B, S100A6, GPNMB, CD90, SOX10 to name a few have established association with gliomagenesis, whereas genes such as ITM2A, KRBOX1, PRR34-AS1, SLCO4A1 and novel gene ENSG00000154553 have no known association with the disease (Avril et al., 2017, p. 90; Donato et al., 2017; Ferletta et al., 2007, p. 10; Frauchiger et al., 2019; Liguori et al., 2020). Similarly downregulated genes with established association are S100A11, UBB, MGST1, SERPINF1 and SPARCL1, while no previous association has been established for XLOC_02 9252 (novel gene), FBN2, SFTA1P, OMD, XLOC_01 2003 (novel gene), XLOC_04 7367 (novel gene) (Armento et al., 2017; Gagliardi et al., 2020; Kedves et al., 2017; Tu et al., 2019, p. 11; Xu et al., 2017). 


\section{Discussion}

The origin of GBM from cancer stem cells or via transformation of normal neural stem cells, still remains largely unknown. Previous studies addressing this question have shown contrasting results, thus making it difficult to establish any one of the theories as the answer (Couturier et al., 2020; Mukherjee, 2020; Yao et al., 2018; Zhao et al., 2019). In this study we have made an attempt to reveal the origin of GBM via RNA-Seq analysis.

To identify differences in gene expression between normal NSCs and GSCs, RNA-Seq analysis was performed on RNA-seq samples obtained from both cell populations. Analysis revealed that both cell populations clustered separately on PCA, depicting the vast genetic differences between the two populations of stem cells. Further, removal of the outlier while performing PCA increased the variance contributed by principal component (PC1) significantly representing substantial variability across samples. The outlier GSC sample, that clustered closer to normal NSCs (also shown in the cluster dendrogram), is of utmost importance as it indicates that the outlier could have genetic similarities with both NSCs and GSCs. This hints towards the theory that GBM may develop via accumulation of mutations in the normal NSCs thus transforming to GSCs. Further studies on the same would be able to divulge the series of events that take place during this transformation.

Based on differential gene expression analysis using DESeq2, we observed 192 genes that were significantly (adjusted P-value $<0.05, \log 2$ fold change $\geq 3.0$ (for GSCs) and $\leq-3.0$ (for NSCs)) upregulated and 156 genes that were downregulated in GSCs in comparison to NSCs. Furthermore, to get a manageable gene set, we selected only the top 50 genes, i.e. top 25 upregulated and top 25 downregulated genes with highest fold change values in GSC vs. NSCs samples. Next, the PCA plot and dendrogram from Hierarchical clustering indicated their significance in determining the differences between GSCs and NSCs. A heat map generated from these genes showed that most genes upregulated in GSCs were downregulated in NSCs and vice versa, highlighting differential expression in both populations.

Gene ontology analysis performed on DAVID using significant gene sets showed no obvious involvement of genes, specifically in gliomagenesis, via functional annotation and clustering. However, hits were obtained for genes associated with cell-adhesion, migration and invasion, indicating that their possible dysregulation may have led to tumorigenesis. Further, pathway 
analysis demonstrated a better understanding of the involvement of the gene sets in pathways representing the hallmarks of cancer such as cell growth, survival, proliferation, adhesion, migration, invasion, growth suppression, apoptosis, angiogenesis and vascular permeability. For instance, we observed the activation of the TGF- $\beta$ pathway. Previous studies have shown that glioma stem cells release TGF- $\beta$ and activate this notorious signaling pathway, to induce epithelial-mesenchymal transition (EMT) and increase the invasiveness of the glioma (Ye et al., 2012). Activation of the Wnt-signaling pathway was also seen, however, not many studies have defined its role in GBM pathogenesis, and thus, it would be interesting to understand its function in the etiology of this cancer (Guan et al., 2020). Another important pathway identified in our study was the VEGF signaling pathway, a known pathway activated in GSCs, inducing cancerstem cell proliferation and therefore, a potential therapeutic target for GBM (Xu et al., 2013). Other pathways associated with normal functioning of neurons were also observed that included the calcium signaling, axon guidance and presynaptic-postsynaptic pathways. Previous studies have their involvement in the initiation, development and prognosis of GBM (Li et al., 2019; Yang et al., 2019).

This study was able to identify several target genes whose role in gliomagenesis remains largely unclear. Studying their functionality in the future may reveal key biomarkers or drug targets that could be exploited for GBM.

\section{Conclusion}

Differences in gene expression between glioma stem cells and normal neural stem cells were identified using RNA-Seq analysis. Discovery of novel genes and genes with no known association in gliomagenesis were important outcomes of our study. Studying the outlier (SRR9200898_PE) in further detail would most likely reveal important clues to the etiology of this fatal cancer.

\section{Limitations of the study}

We selected a small sample size of NSCs and GSCs that were derived from a heterogeneous population with unknown demographic features of the patients, and lacked data regarding their treatment status. This prevents the generalizability of our results to a larger population. As part of a future study, it would be interesting to understand the changes in gene expression in both NSCs and GSCs post therapy with current gold standards of treatment for GBM versus new modalities 
such as nanotherapy and precision drugs like bevacizumab (Gilbert et al., 2014; Grauer et al., 2019; Stupp et al., 2009b).

\section{Acknowledgements}

I would like to thank the entire team at Pine Biotech for their invaluable guidance, training and resources provided for this project. The project was completed during the course of the OmicsLogic Fellowship Program. Pipelines for the study were prepared using the T-BioInfo server.

\section{Authors's Contribution}

Urja Parekh proposed the research idea, conducted the analysis and wrote the article. Mentorship and guidance was provided by Dr. Mohit Mazumdar and Elia Brodsky through the course of the project. Dr. Harpreet Kaur reviewed and edited the article.

\section{Conflicts of Interest Statement}

None declared.

\section{References}

1. Armento, A., Ilina, E.I., Kaoma, T., Muller, A., Vallar, L., Niclou, S.P., Krüger, M.A., Mittelbronn, M., Naumann, U., 2017. Carboxypeptidase E transmits its anti-migratory function in glioma cells via transcriptional regulation of cell architecture and motility regulating factors. Int. J. Oncol. 51, 702-714. https://doi.org/10.3892/ijo.2017.4051

2. Avril, T., Etcheverry, A., Pineau, R., Obacz, J., Jegou, G., Jouan, F., Reste, P.-J.L., Hatami, M., Colen, R.R., Carlson, B.L., Decker, P.A., Sarkaria, J.N., Vauléon, E., Chiforeanu, D.C., Clavreul, A., Mosser, J., Chevet, E., Quillien, V., 2017. CD90 Expression Controls Migration and Predicts Dasatinib Response in Glioblastoma. Clin. Cancer Res. 23, 7360-7374. https://doi.org/10.1158/1078-0432.CCR-17-1549

3. Bacaj, T., Wu, D., Yang, X., Morishita, W., Zhou, P., Xu, W., Malenka, R.C., Südhof, T.C., 2013. Synaptotagmin-1 and Synaptotagmin-7 Trigger Synchronous and Asynchronous Phases of Neurotransmitter Release. Neuron 80, 947-959. https://doi.org/10.1016/j.neuron.2013.10.026 
4. Ban, M.J., Ji, S.H., Lee, C.-K., Bae, S.B., Kim, H.J., Ahn, T.S., Lee, M.S., Baek, M.-J., Jeong, D., 2017. Solute carrier organic anion transporter family member 4A1 (SLCO4A1) as a prognosis marker of colorectal cancer. J. Cancer Res. Clin. Oncol. 143, 1437-1447. https://doi.org/10.1007/s00432-017-2393-7

5. Bassani, S., Cingolani, L.A., Valnegri, P., Folci, A., Zapata, J., Gianfelice, A., Sala, C., Goda, Y., Passafaro, M., 2012. The X-Linked Intellectual Disability Protein TSPAN7 Regulates Excitatory Synapse Development and AMPAR Trafficking. Neuron 73, $1143-$ 1158. https://doi.org/10.1016/j.neuron.2012.01.021

6. Bouvier, C., Bartoli, C., Aguirre-Cruz, L., Virard, I., Colin, C., Fernandez, C., Gouvernet, J., Figarella-Branger, D., 2003. Shared oligodendrocyte lineage gene expression in gliomas and oligodendrocyte progenitor cells. J. Neurosurg. 99, 344-350. https://doi.org/10.3171/jns.2003.99.2.0344

7. Bräutigam, L., Zhang, J., Dreij, K., Spahiu, L., Holmgren, A., Abe, H., Tew, K.D., Townsend, D.M., Kelner, M.J., Morgenstern, R., Johansson, K., 2018. MGST1, a GSH transferase/peroxidase essential for development and hematopoietic stem cell differentiation. Redox Biol. 17, 171-179. https://doi.org/10.1016/j.redox.2018.04.013

8. Bruning-Richardson, A., Droop, A., Tams, D., Boissinot, M., Hayes, J., Cheng, V., Cockle, J., Ismail, A., Morton, R., Esteves, F., Mittelbronn, M., Lawler, S., Short, S., Mavria, G., 2018. Identification of transcriptional targets of GSK3 involved in glioblastoma invasion. Neuro-Oncol. 20, i26-i26.

https://doi.org/10.1093/neuonc/nox238.117

9. Capone, M., Bryant, J.M., Sutkowski, N., Haque, A., 2016. Fc Receptor-Like Proteins in Pathophysiology of B-cell Disorder. J. Clin. Cell. Immunol. 7. https://doi.org/10.4172/2155-9899.1000427

10. Chakravarti, S., 2002. Functions of lumican and fibromodulin: Lessons from knockout mice. Glycoconj. J. 19, 287-293. https://doi.org/10.1023/A:1025348417078

11. Charbonneau, N.L., Dzamba, B.J., Ono, R.N., Keene, D.R., Corson, G.M., Reinhardt, D.P., Sakai, L.Y., 2003. Fibrillins Can Co-assemble in Fibrils, but Fibrillin Fibril Composition Displays Cell-specific Differences *. J. Biol. Chem. 278, 2740-2749. https://doi.org/10.1074/jbc.M209201200 
12. Cheng, W.-Y., Kandel, J.J., Yamashiro, D.J., Canoll, P., Anastassiou, D., 2012. A MultiCancer Mesenchymal Transition Gene Expression Signature Is Associated with Prolonged Time to Recurrence in Glioblastoma. PLoS ONE 7. https://doi.org/10.1371/journal.pone.0034705

13. Couturier, C.P., Ayyadhury, S., Le, P.U., Nadaf, J., Monlong, J., Riva, G., Allache, R., Baig, S., Yan, X., Bourgey, M., Lee, C., Wang, Y.C.D., Wee Yong, V., Guiot, M.-C., Najafabadi, H., Misic, B., Antel, J., Bourque, G., Ragoussis, J., Petrecca, K., 2020. Single-cell RNA-seq reveals that glioblastoma recapitulates a normal neurodevelopmental hierarchy. Nat. Commun. 11, 3406. https://doi.org/10.1038/s41467020-17186-5

14. Dai, J., Bercury, K.K., Ahrendsen, J.T., Macklin, W.B., 2015. Olig1 Function Is Required for Oligodendrocyte Differentiation in the Mouse Brain. J. Neurosci. 35, 4386-4402. https://doi.org/10.1523/JNEUROSCI.4962-14.2015

15. Deleersnijder, W., Hong, G., Cortvrindt, R., Poirier, C., Tylzanowski, P., Pittois, K., Marck, E.V., Merregaert, J., 1996. Isolation of Markers for Chondro-osteogenic Differentiation Using cDNA Library Subtraction: MOLECULAR CLONING AND CHARACTERIZATION OF A GENE BELONGING TO A NOVEL MULTIGENE FAMILY OF INTEGRAL MEMBRANE PROTEINS *. J. Biol. Chem. 271, 1947519482. https://doi.org/10.1074/jbc.271.32.19475

16. Donato, R., Sorci, G., Giambanco, I., 2017. S100A6 protein: functional roles. Cell. Mol. Life Sci. 74, 2749-2760. https://doi.org/10.1007/s00018-017-2526-9

17. Dou, T., Fu, M., Wang, Y., Zhao, Y., Wang, Z., Bian, Z., Zhou, Y., 2013. Signatures of positive selection in LY96 gene in vertebrates. J. Biosci. 38, 899-904.

https://doi.org/10.1007/s12038-013-9377-9

18. Dube, S., Thomas, A., Abbott, L., Benz, P., Mitschow, C., Dube, D.K., Poiesz, B.J., 2016. Expression of tropomyosin 2 gene isoforms in human breast cancer cell lines.

Oncol. Rep. 35, 3143-3150. https://doi.org/10.3892/or.2016.4732

19. Farace, C., Oliver, J.A., Melguizo, C., Alvarez, P., Bandiera, P., Rama, A.R., Malaguarnera, G., Ortiz, R., Madeddu, R., Prados, J., 2015. Microenvironmental Modulation of Decorin and Lumican in Temozolomide-Resistant Glioblastoma and 
Neuroblastoma Cancer Stem-Like Cells. PLOS ONE 10, e0134111.

https://doi.org/10.1371/journal.pone.0134111

20. Feng, W., Orlandi, R., Zhao, N., Carcangiu, M.L., Tagliabue, E., Xu, J., Bast, R.C., Yu, Y., 2010. Tumor suppressor genes are frequently methylated in lymph node metastases of breast cancers. BMC Cancer 10, 378. https://doi.org/10.1186/1471-2407-10-378

21. Ferletta, M., Uhrbom, L., Olofsson, T., Pontén, F., Westermark, B., 2007. Sox10 has a broad expression pattern in gliomas and enhances platelet-derived growth factor-B-induced gliomagenesis. Mol. Cancer Res. MCR 5, 891-897. https://doi.org/10.1158/1541-7786.MCR-07-0113

22. Frauchiger, A.L., Dummer, R., Mangana, J., 2019. Serum S100B Levels in Melanoma. Methods Mol. Biol. Clifton NJ 1929, 691-700. https://doi.org/10.1007/978-1-4939-90306_43

23. Gagliardi, F., Narayanan, A., Gallotti, A.L., Pieri, V., Mazzoleni, S., Cominelli, M., Rezzola, S., Corsini, M., Brugnara, G., Altabella, L., Politi, L.S., Bacigaluppi, M., Falini, A., Castellano, A., Ronca, R., Poliani, P.L., Mortini, P., Galli, R., 2020. Enhanced SPARCL1 expression in cancer stem cells improves preclinical modeling of glioblastoma by promoting both tumor infiltration and angiogenesis. Neurobiol. Dis. 134, 104705. https://doi.org/10.1016/j.nbd.2019.104705

24. Gagliardi, F., Narayanan, A., Mortini, P., 2017. SPARCL1 a novel player in cancer biology. Crit. Rev. Oncol. Hematol. 109, 63-68. https://doi.org/10.1016/j.critrevonc.2016.11.013

25. Gao, H., Zhang, I.Y., Zhang, L., Song, Y., Liu, S., Ren, H., Liu, H., Zhou, H., Su, Y., Yang, Y., Badie, B., 2018. S100B suppression alters polarization of infiltrating myeloidderived cells in gliomas and inhibits tumor growth. Cancer Lett. 439, 91-100. https://doi.org/10.1016/j.canlet.2018.07.034

26. Gilbert, M.R., Dignam, J.J., Armstrong, T.S., Wefel, J.S., Blumenthal, D.T., Vogelbaum, M.A., Colman, H., Chakravarti, A., Pugh, S., Won, M., Jeraj, R., Brown, P.D., Jaeckle, K.A., Schiff, D., Stieber, V.W., Brachman, D.G., Werner-Wasik, M., Tremont-Lukats, I.W., Sulman, E.P., Aldape, K.D., Curran, W.J., Mehta, M.P., 2014. A Randomized Trial of Bevacizumab for Newly Diagnosed Glioblastoma. N. Engl. J. Med. 370, 699-708. https://doi.org/10.1056/NEJMoa1308573 
27. Grauer, O., Jaber, M., Hess, K., Weckesser, M., Schwindt, W., Maring, S., Wölfer, J., Stummer, W., 2019. Combined intracavitary thermotherapy with iron oxide nanoparticles and radiotherapy as local treatment modality in recurrent glioblastoma patients. J. Neurooncol. 141, 83-94. https://doi.org/10.1007/s11060-018-03005-X

28. Guan, M., Pang, C.-P., Yam, H.-F., Cheung, K.-F., Liu, W.-W., Lu, Y., 2004. Inhibition of glioma invasion by overexpression of pigment epithelium-derived factor. Cancer Gene Ther. 11, 325-332. https://doi.org/10.1038/sj.cgt.7700675

29. Guan, R., Zhang, X., Guo, M., 2020. Glioblastoma stem cells and Wnt signaling pathway: molecular mechanisms and therapeutic targets. Chin. Neurosurg. J. 6, 25. https://doi.org/10.1186/s41016-020-00207-z

30. Harris, M.A., Yang, H., Low, B.E., Mukherje, J., Guha, A., Bronson, R.T., Shultz, L.D., Israel, M.A., Yun, K., 2008. Cancer Stem Cells Are Enriched in the Side Population Cells in a Mouse Model of Glioma. Cancer Res. 68, 10051-10059. https://doi.org/10.1158/0008-5472.CAN-08-0786

31. Hau, P., Apfel, R., Wiese, P., Tschertner, I., Blesch, A., Bogdahn, U., 2002. Melanomainhibiting activity (MIA/CD-RAP) is expressed in a variety of malignant tumors of mainly neuroectodermal origin. Anticancer Res. 22, 577-583.

32. Holla, F.K., Postma, T.J., Blankenstein, M.A., van Mierlo, T.J.M., Vos, M.J., Sizoo, E.M., de Groot, M., Uitdehaag, B.M.J., Buter, J., Klein, M., Reijneveld, J.C., Heimans, J.J., 2016. Prognostic value of the S100B protein in newly diagnosed and recurrent glioma patients: a serial analysis. J. Neurooncol. 129, 525-532. https://doi.org/10.1007/s11060-016-2204-Z

33. Hong, Y.B., Joo, J., Hyun, Y.S., Kwak, G., Choi, Y.-R., Yeo, H.K., Jwa, D.H., Kim, E.J., Mo, W.M., Nam, S.H., Kim, S.M., Yoo, J.H., Koo, H., Park, H.T., Chung, K.W., Choi, B.-O., 2016. A Mutation in PMP2 Causes Dominant Demyelinating Charcot-MarieTooth Neuropathy. PLOS Genet. 12, e1005829.

https://doi.org/10.1371/journal.pgen.1005829

34. Huang, C., Zhao, J., Lv, L., Chen, Yi-bing, Li, Y., Jiang, S., Wang, W., Pan, K., Zheng, Y., Zhao, B., Wang, D., Chen, Yong-ming, Yang, L., Zhou, Z., Xia, J., 2013. Decreased Expression of AZGP1 Is Associated with Poor Prognosis in Primary Gastric Cancer. PLoS ONE 8. https://doi.org/10.1371/journal.pone.0069155 
35. Huang, G.-Q., Ke, Z.-P., Hu, H.-B., Gu, B., 2017. Co-expression network analysis of long noncoding RNAs (IncRNAs) and cancer genes revealsSFTA1P and CASC2abnormalities in lung squamous cell carcinoma. Cancer Biol. Ther. 18, 115-122. https://doi.org/10.1080/15384047.2017.1281494

36. Jain, A.K., Xi, Y., McCarthy, R., Allton, K., Akdemir, K.C., Patel, L.R., Aronow, B., Lin, C., Li, W., Yang, L., Barton, M.C., 2016. LncPRESS1 Is a p53-Regulated LncRNA that Safeguards Pluripotency by Disrupting SIRT6-Mediated De-acetylation of Histone H3K56. Mol. Cell 64, 967-981. https://doi.org/10.1016/j.molcel.2016.10.039

37. Jones, K.A., Bossler, A.D., Bellizzi, A.M., Snow, A.N., 2019. BCR-NTRK2 fusion in a low-grade glioma with distinctive morphology and unexpected aggressive behavior. Mol. Case Stud. 5, a003855. https://doi.org/10.1101/mcs.a003855

38. Ju, Y.-T., Chang, A.C.Y., She, B.-R., Tsaur, M.-L., Hwang, H.-M., Chao, C.C.-K., Cohen, S.N., Lin-Chao, S., 1998. gas7: A gene expressed preferentially in growtharrested fibroblasts and terminally differentiated Purkinje neurons affects neurite formation. Proc. Natl. Acad. Sci. 95, 11423-11428.

https://doi.org/10.1073/pnas.95.19.11423

39. Kedves, A.T., Gleim, S., Liang, X., Bonal, D.M., Sigoillot, F., Harbinski, F., Sanghavi, S., Benander, C., George, E., Gokhale, P.C., Nguyen, Q.-D., Kirschmeier, P.T., Distel, R.J., Jenkins, J., Goldberg, M.S., Forrester, W.C., 2017. Recurrent ubiquitin B silencing in gynecological cancers establishes dependence on ubiquitin C. J. Clin. Invest. 127, 4554-4568. https://doi.org/10.1172/JCI92914

40. Kesherwani, V., Shukla, M., Coulter, D.W., Sharp, J.G., Joshi, S.S., Chaturvedi, N.K., 2020. Long non-coding RNA profiling of pediatric Medulloblastoma. BMC Med.

Genomics 13, 87. https://doi.org/10.1186/s12920-020-00744-7

41. Khosravi, P., Zahiri, J., Gazestani, V.H., Mirkhalaf, S., Akbarzadeh, M., Sadeghi, M., Goliaei, B., 2014. Analysis of Candidate Genes Has Proposed the Role of Y Chromosome in Human Prostate Cancer. Iran. J. Cancer Prev. 7, 204-211.

42. Kim, K.S., Kim, J.E., Choi, K.J., Bae, S., Kim, D.H., 2014. Characterization of DNA damage-induced cellular senescence by ionizing radiation in endothelial cells. Int. J. Radiat. Biol. 90, 71-80. https://doi.org/10.3109/09553002.2014.859763 
43. Kim, Y.-W., Koul, D., Kim, S.H., Lucio-Eterovic, A.K., Freire, P.R., Yao, J., Wang, J., Almeida, J.S., Aldape, K., Yung, W.K.A., 2013. Identification of prognostic gene signatures of glioblastoma: a study based on TCGA data analysis. Neuro-Oncol. 15, 829839. https://doi.org/10.1093/neuonc/not024

44. Kolb, K., Hellinger, J., Kansy, M., Wegwitz, F., Bauerschmitz, G., Emons, G., Gründker, C., 2020. Influence of ARHGAP29 on the Invasion of Mesenchymal-Transformed Breast Cancer Cells. Cells 9, 2616. https://doi.org/10.3390/cells9122616

45. Kruthika, B.S., Sugur, H., Nandaki, K., Arimappamagan, A., Paturu, K., Santosh, V., 2019. Expression pattern and prognostic significance of myosin light chain 9 (MYL9): a novel biomarker in glioblastoma. J. Clin. Pathol. 72, 677-681.

https://doi.org/10.1136/jclinpath-2019-205834

46. Li, L., Liu, X., Ma, X., Deng, X., Ji, T., Hu, P., Wan, R., Qiu, H., Cui, D., Gao, L., 2019. Identification of key candidate genes and pathways in glioblastoma by integrated bioinformatical analysis. Exp. Ther. Med. 18, 3439-3449.

https://doi.org/10.3892/etm.2019.7975

47. Li, M., Cai, O., Tan, S., 2019. LOXL1-AS1 Drives The Progression Of Gastric Cancer Via Regulating miR-142-5p/PIK3CA Axis. OncoTargets Ther. 12, 11345-11357. https://doi.org/10.2147/OTT.S223702

48. Liguori, M., Digifico, E., Vacchini, A., Avigni, R., Colombo, F.S., Borroni, E.M., Farina, F.M., Milanesi, S., Castagna, A., Mannarino, L., Craparotta, I., Marchini, S., Erba, E., Panini, N., Tamborini, M., Rimoldi, V., Allavena, P., Belgiovine, C., 2020. The soluble glycoprotein NMB (GPNMB) produced by macrophages induces cancer stemness and metastasis via CD44 and IL-33. Cell. Mol. Immunol. 1-12.

https://doi.org/10.1038/s41423-020-0501-0

49. Lin, W., Gao, L., Jiang, W., Niu, C., Yuan, K., Hu, X., Ma, R., Huang, Z., 2019. The role of osteomodulin on osteo/odontogenic differentiation in human dental pulp stem cells. BMC Oral Health 19, 22. https://doi.org/10.1186/s12903-018-0680-6

50. Liu, Z.-Q., Ren, J.-J., Zhao, J.-L., Zang, J., Long, Q.-F., Du, J.-J., Jia, X.-T., Gu, N.-B., Di, Z.-L., Qian, Y.-H., Li, S.-Z., 2020. MicroRNA-144 represses gliomas progression and elevates susceptibility to Temozolomide by targeting CAV2 and FGF7. Sci. Rep. 10, 4155. https://doi.org/10.1038/s41598-020-60218-9 
51. Lu, D.-D., Chen, Y.-C., Zhang, X.-R., Cao, X.-R., Jiang, H.-Y., Yao, L., 2003. The relationship between metallothionein-1F (MT1F) gene and hepatocellular carcinoma. Yale J. Biol. Med. 76, 55-62.

52. Luo, X., Xu, S., Zhong, Y., Tu, T., Xu, Y., Li, X., Wang, B., Yang, F., 2019. High gene expression levels of VEGFA and CXCL8 in the peritumoral brain zone are associated with the recurrence of glioblastoma: A bioinformatics analysis. Oncol. Lett. 18, 61716179. https://doi.org/10.3892/ol.2019.10988

53. Luo, X.-G., Zhang, C.-L., Zhao, W.-W., Liu, Z.-P., Liu, L., Mu, A., Guo, S., Wang, N., Zhou, H., Zhang, T.-C., 2014. Histone methyltransferase SMYD3 promotes MRTF-Amediated transactivation of MYL9 and migration of MCF-7 breast cancer cells. Cancer Lett. 344, 129-137. https://doi.org/10.1016/j.canlet.2013.10.026

54. Maurin, M.-L., Labrune, P., Brisset, S., Lorc'h, M.L., Pineau, D., Castel, C., Romana, S., Tachdjian, G., 2009. Molecular cytogenetic characterization of a 4p15.1-pter duplication and a 4q35.1-qter deletion in a recombinant of chromosome 4 pericentric inversion. Am. J. Med. Genet. A. 149A, 226-231. https://doi.org/10.1002/ajmg.a.32603

55. Mehrian-Shai, R., Yalon, M., Simon, A.J., Eyal, E., Pismenyuk, T., Moshe, I., Constantini, S., Toren, A., 2015. High metallothionein predicts poor survival in glioblastoma multiforme. BMC Med. Genomics 8. https://doi.org/10.1186/s12920-0150137-6

56. Ming, L., Weiping, X., Yimin, L., Wangqing, C., Jiahao, L., Kaishu, L., 2017. Effect of PDLIM4 gene on the prognosis of glioma and its cell radiosensitivity. Chin. J. Radiol. Med. Prot. 37, 725-729, 762. https://doi.org/10.3760/cma.j.issn.0254-5098.2017.10.001

57. Mitchell, C.B., Black, B., Sun, F., Chrzanowski, W., Cooper-White, J., Maisonneuve, B., Stringer, B., Day, B., Biro, M., O’Neill, G.M., 2019. Tropomyosin Tpm 2.1 loss induces glioblastoma spreading in soft brain-like environments. J. Neurooncol. 141, 303-313. https://doi.org/10.1007/s11060-018-03049-z

58. Miyamoto, Y., Torii, T., Tanoue, A., Yamauchi, J., 2012. Pelizaeus-Merzbacher diseaseassociated proteolipid protein 1 inhibits oligodendrocyte precursor cell differentiation via extracellular-signal regulated kinase signaling. Biochem. Biophys. Res. Commun. 424, 262-268. https://doi.org/10.1016/j.bbrc.2012.06.101 
59. Moreno, D., Sussuchi, L., Leal, L., Sorroche, B., Santana, I., Matsushita, M., Bhat, K., Lawlew, S., Reis, R., 2021. Abstract PO005: The overexpression of Immune oncologyrelated genes NFSF14, LY96, SLC11A1 and CTSL are associated with short survival in glioblastoma. Cancer Immunol. Res. 9, PO005-PO005. https://doi.org/10.1158/23266074.TUMIMM20-PO005

60. Mori, M., Shimada, H., Gunji, Y., Matsubara, H., Hayashi, H., Nimura, Y., Kato, M., Takiguchi, M., Ochiai, T., Seki, N., 2004. S100A11 gene identified by in-house cDNA microarray as an accurate predictor of lymph node metastases of gastric cancer. Oncol. Rep. 11, 1287-1293. https://doi.org/10.3892/or.11.6.1287

61. Mukherjee, S., 2020. Quiescent stem cell marker genes in glioma gene networks are sufficient to distinguish between normal and glioblastoma (GBM) samples. Sci. Rep. 10. https://doi.org/10.1038/s41598-020-67753-5

62. Ninomiya, K., Miyamoto, T., Imai, J., Fujita, N., Suzuki, T., Iwasaki, R., Yagi, M., Watanabe, S., Toyama, Y., Suda, T., 2007. Osteoclastic activity induces osteomodulin expression in osteoblasts. Biochem. Biophys. Res. Commun. 362, 460-466. https://doi.org/10.1016/j.bbrc.2007.07.193

63. Ochocka, N., Segit, P., Walentynowicz, K.A., Wojnicki, K., Cyranowski, S., Swatler, J., Mieczkowski, J., Kaminska, B., 2019. Single-cell RNA sequencing reveals functional heterogeneity and sex differences of glioma-associated brain macrophages. bioRxiv 752949. https://doi.org/10.1101/752949

64. Ocklenburg, S., Anderson, C., Gerding, W.M., Fraenz, C., Schlüter, C., Friedrich, P., Raane, M., Mädler, B., Schlaffke, L., Arning, L., Epplen, J.T., Güntürkün, O., Beste, C., Genç, E., 2019. Myelin Water Fraction Imaging Reveals Hemispheric Asymmetries in Human White Matter That Are Associated with Genetic Variation in PLP1. Mol. Neurobiol. 56, 3999-4012. https://doi.org/10.1007/s12035-018-1351-y

65. Ono, Y., Chiba, S., Yano, H., Nakayama, N., Saio, M., Tsuruma, K., Shimazawa, M., Iwama, T., Hara, H., 2016. Glycoprotein nonmetastatic melanoma protein B (GPNMB) promotes the progression of brain glioblastoma via $\mathrm{Na}+/ \mathrm{K}+-\mathrm{ATPase}$. Biochem. Biophys. Res. Commun. 481, 7-12. https://doi.org/10.1016/j.bbrc.2016.11.034

66. Osti, D., Del Bene, M., Rappa, G., Santos, M., Matafora, V., Richichi, C., Faletti, S., Beznoussenko, G.V., Mironov, A., Bachi, A., Fornasari, L., Bongetta, D., Gaetani, P., 
DiMeco, F., Lorico, A., Pelicci, G., 2019. Clinical Significance of Extracellular Vesicles in Plasma from Glioblastoma Patients. Clin. Cancer Res. 25, 266-276.

https://doi.org/10.1158/1078-0432.CCR-18-1941

67. Park, S., Zhang, X., Li, C., Yin, C., Li, J., Fallon, J.T., Huang, W., Xu, D., 2017. Singlecell RNA Sequencing Reveals an Altered Gene Expression Pattern as a Result of CRISPR/cas9-mediated Deletion of Gene 33/Mig6 and Chronic Exposure to Hexavalent Chromium in Human Lung Epithelial Cells. Toxicol. Appl. Pharmacol. 330, 30-39. https://doi.org/10.1016/j.taap.2017.07.003

68. Pattwell, S.S., Arora, S., Cimino, P.J., Ozawa, T., Szulzewsky, F., Hoellerbauer, P., Bonifert, T., Hoffstrom, B.G., Boiani, N.E., Bolouri, H., Correnti, C.E., Oldrini, B., Silber, J.R., Squatrito, M., Paddison, P.J., Holland, E.C., 2020a. A kinase-deficient NTRK2 splice variant predominates in glioma and amplifies several oncogenic signaling pathways. Nat. Commun. 11, 2977. https://doi.org/10.1038/s41467-020-16786-5

69. Pattwell, S.S., Konnick, E.Q., Liu, Y.J., Yoda, R.A., Sekhar, L.N., Cimino, P.J., 2020 b. Neurotrophic Receptor Tyrosine Kinase 2 (NTRK2) Alterations in Low-Grade Gliomas: Report of a Novel Gene Fusion Partner in a Pilocytic Astrocytoma and Review of the Literature. Case Rep. Pathol. 2020. https://doi.org/10.1155/2020/5903863

70. Poser, I., Tatzel, J., Kuphal, S., Bosserhoff, A.K., 2004. Functional role of MIA in melanocytes and early development of melanoma. Oncogene 23, 6115-6124. https://doi.org/10.1038/sj.onc. 1207797

71. Pozniak, C.D., Langseth, A.J., Dijkgraaf, G.J.P., Choe, Y., Werb, Z., Pleasure, S.J., 2010. Sox10 directs neural stem cells toward the oligodendrocyte lineage by decreasing Suppressor of Fused expression. Proc. Natl. Acad. Sci. U. S. A. 107, 21795-21800. https://doi.org/10.1073/pnas.1016485107

72. Rajaraman, P., Brenner, A.V., Butler, M.A., Wang, S.S., Pfeiffer, R.M., Ruder, A.M., Linet, M.S., Yeager, M., Wang, Z., Orr, N., Fine, H.A., Kwon, D., Thomas, G., Rothman, N., Inskip, P.D., Chanock, S.J., 2009. Common Variation in Genes Related to Innate Immunity and Risk of Adult Glioma. Cancer Epidemiol. Biomark. Prev. Publ. Am. Assoc. Cancer Res. Cosponsored Am. Soc. Prev. Oncol. 18, 1651-1658. https://doi.org/10.1158/1055-9965.EPI-08-1041 
73. Rehberg, S., Lischka, P., Glaser, G., Stamminger, T., Wegner, M., Rosorius, O., 2002. Sox10 is an active nucleocytoplasmic shuttle protein, and shuttling is crucial for Sox10mediated transactivation. Mol. Cell. Biol. 22, 5826-5834.

https://doi.org/10.1128/mcb.22.16.5826-5834.2002

74. Santiago, T., Kulemzin, S.V., Reshetnikova, E.S., Chikaev, N.A., Volkova, O.Y., Mechetina, L.V., Zhao, M., Davis, R.S., Taranin, A.V., Najakshin, A.M., Hendershot, L.M., Burrows, P.D., 2011. FCRLA is a resident endoplasmic reticulum protein that associates with intracellular Igs, IgM, IgG and IgA. Int. Immunol. 23, 43-53. https://doi.org/10.1093/intimm/dxq456

75. Sauzay, C., Voutetakis, K., Chatziioannou, A., Chevet, E., Avril, T., 2019. CD90/Thy-1, a Cancer-Associated Cell Surface Signaling Molecule. Front. Cell Dev. Biol. 7. https://doi.org/10.3389/fcell.2019.00066

76. Scholz, N., Kurian, K.M., Siebzehnrubl, F.A., Licchesi, J.D.F., 2020. Targeting the Ubiquitin System in Glioblastoma. Front. Oncol. 10. https://doi.org/10.3389/fonc.2020.574011

77. Shimizu, T., Hibi, M., 2009. Formation and patterning of the forebrain and olfactory system by zinc-finger genes Fezf1 and Fezf2. Dev. Growth Differ. 51, 221-231. https://doi.org/10.1111/j.1440-169X.2009.01088.x

78. Sorci, G., Riuzzi, F., Arcuri, C., Tubaro, C., Bianchi, R., Giambanco, I., Donato, R., 2013. S100B protein in tissue development, repair and regeneration. World J. Biol. Chem. 4, 1-12. https://doi.org/10.4331/wjbc.v4.i1.1

79. Sowa, G., 2011. Novel Insights into the Role of Caveolin-2 in Cell- and Tissue-Specific Signaling and Function. Biochem. Res. Int. 2011, e809259.

https://doi.org/10.1155/2011/809259

80. Stupp, R., Hegi, M.E., Mason, W.P., 2009. Effects of radiotherapy with concomitant and adjuvant temozolomide versus radiotherapy alone on survival in glioblastoma in a randomised phase III study: 5-year analysis of the EORTC-NCIC trial 10, 8.

81. Sun, L., Xu, X., Chen, Y., Zhou, Y., Tan, R., Qiu, H., Jin, L., Zhang, W., Fan, R., Hong, W., Wang, T., 2018. Rab34 regulates adhesion, migration, and invasion of breast cancer cells. Oncogene 37, 3698-3714. https://doi.org/10.1038/s41388-018-0202-7 
82. Sun, X., Johnson, J., St. John, J.C., 2018. Global DNA methylation synergistically regulates the nuclear and mitochondrial genomes in glioblastoma cells. Nucleic Acids Res. 46, 5977-5995. https://doi.org/10.1093/nar/gky339

83. Tan, X., Chen, M., 2014. MYLK and MYL9 expression in non-small cell lung cancer identified by bioinformatics analysis of public expression data. Tumor Biol. 35, 1218912200. https://doi.org/10.1007/s13277-014-2527-3

84. Tatenhorst, L., Püttmann, S., Senner, V., Paulus, W., 2005. Genes Associated with Fast Glioma Cell Migration In Vitro and In Vivo. Brain Pathol. 15, 46-54. https://doi.org/10.1111/j.1750-3639.2005.tb00099.x

85. Tayrac, M. de, Aubry, M., Saïkali, S., Etcheverry, A., Surbled, C., Guénot, F., Galibert, M.-D., Hamlat, A., Lesimple, T., Quillien, V., Menei, P., Mosser, J., 2011. A 4-Gene Signature Associated with Clinical Outcome in High-Grade Gliomas. Clin. Cancer Res. 17, 317-327. https://doi.org/10.1158/1078-0432.CCR-10-1126

86. Torre, M., Vasudevaraja, V., Serrano, J., DeLorenzo, M., Malinowski, S., Blandin, A.-F., Pages, M., Ligon, A.H., Dong, F., Meredith, D.M., Nasrallah, M.P., Horbinski, C., Dahiya, S., Ligon, K.L., Santi, M., Ramkissoon, S.H., Filbin, M.G., Snuderl, M., Alexandrescu, S., 2020. Molecular and clinicopathologic features of gliomas harboring NTRK fusions. Acta Neuropathol. Commun. 8, 107. https://doi.org/10.1186/s40478-02000980-Z

87. Toyoda, Y., Takada, T., Miyata, H., Matsuo, H., Kassai, H., Nakao, K., Nakatochi, M., Kawamura, Y., Shimizu, S., Shinomiya, N., Ichida, K., Hosoyamada, M., Aiba, A., Suzuki, H., 2020. Identification of GLUT12/SLC2A12 as a urate transporter that regulates the blood urate level in hyperuricemia model mice. Proc. Natl. Acad. Sci. 117, 18175-18177. https://doi.org/10.1073/pnas.2006958117

88. Tu, Y., Xie, P., Du, X., Fan, L., Bao, Z., Sun, G., zhao, P., Chao, H., Li, C., Zeng, A., Pan, M., Ji, J., 2019. S100A11 functions as novel oncogene in glioblastoma via S100A11/ANXA2/NF-кB positive feedback loop. J. Cell. Mol. Med. 23, 6907-6918. https://doi.org/10.1111/jcmm.14574

89. Turaga, S.M., Lathia, J.D., 2016. Adhering towards tumorigenicity: altered adhesion mechanisms in glioblastoma cancer stem cells. CNS Oncol. 5, 251-259. https://doi.org/10.2217/cns-2016-0015 
90. van Loon, K., Yemelyanenko-Lyalenko, J., Margadant, C., Griffioen, A.W., Huijbers, E.J.M., 2020. Role of fibrillin-2 in the control of TGF- $\beta$ activation in tumor angiogenesis and connective tissue disorders. Biochim. Biophys. Acta Rev. Cancer 1873, 188354. https://doi.org/10.1016/j.bbcan.2020.188354

91. Vanaja, D.K., Ballman, K.V., Morlan, B.W., Cheville, J.C., Neumann, R.M., Lieber, M.M., Tindall, D.J., Young, C.Y.F., 2006. PDLIM4 repression by hypermethylation as a potential biomarker for prostate cancer. Clin. Cancer Res. 12, 1128-1136. https://doi.org/10.1158/1078-0432.CCR-05-2072

92. Varga, I., Hutóczki, G., Petrás, M., Scholtz, B., Mikó, E., Kenyeres, A., Tóth, J., Zahuczky, G., Bognár, L., Hanzély, Z., Klekner, A., 2010. Expression of InvasionRelated Extracellular Matrix Molecules in Human Glioblastoma Versus Intracerebral Lung Adenocarcinoma Metastasis. Cent. Eur. Neurosurg. 71, 173-180. https://doi.org/10.1055/s-0030-1249698

93. Vital, A.L., Tabernero, M.D., Castrillo, A., Rebelo, O., Tão, H., Gomes, F., Nieto, A.B., Resende Oliveira, C., Lopes, M.C., Orfao, A., 2010. Gene expression profiles of human glioblastomas are associated with both tumor cytogenetics and histopathology. NeuroOncol. 12, 991-1003. https://doi.org/10.1093/neuonc/noq050

94. Wang, C., Pan, Y.-H., Wang, Y., Blatt, G., Yuan, X.-B., 2019. Segregated expressions of autism risk genes Cdh11 and Cdh9 in autism-relevant regions of developing cerebellum. Mol. Brain 12, 40. https://doi.org/10.1186/s13041-019-0461-4

95. Wang, H., Gao, Y., Chen, L., Li, Y., Jiang, C., 2015. RAB34 was a progression- and prognosis-associated biomarker in gliomas. Tumour Biol. J. Int. Soc. Oncodevelopmental Biol. Med. 36, 1573-1578. https://doi.org/10.1007/s13277-014-2732-0

96. Wang, Q., Williamson, M., Bott, S., Brookman-Amissah, N., Freeman, A., Nariculam, J., Hubank, M.J.F., Ahmed, A., Masters, J.R., 2007. Hypomethylation of WNT5A, CRIP1 and S100P in prostate cancer. Oncogene 26, 6560-6565. https://doi.org/10.1038/sj.onc.1210472

97. Wipfler, K., Cornish, A.S., Guda, C., 2018. Comparative molecular characterization of typical and exceptional responders in glioblastoma. Oncotarget 9, 28421-28433. https://doi.org/10.18632/oncotarget.25420 
98. Wu, Y., Fletcher, M., Gu, Z., Wang, Q., Costa, B., Bertoni, A., Man, K.-H., Schlotter, M., Felsberg, J., Mangei, J., Barbus, M., Gaupel, A.-C., Wang, W., Weiss, T., Eils, R., Weller, M., Liu, H., Reifenberger, G., Korshunov, A., Angel, P., Lichter, P., Herrmann, C., Radlwimmer, B., 2020. Glioblastoma epigenome profiling identifies SOX10 as a master regulator of molecular tumour subtype. Nat. Commun. 11, 6434. https://doi.org/10.1038/s41467-020-20225-w

99. Wu, Y., Richard, J., Wang, S.D., Rath, P., Laterra, J., Xia, S., 2012. Regulation of glioblastoma multiforme stem-like cells by inhibitor of DNA binding proteins and oligodendroglial lineage-associated transcription factors. Cancer Sci. 103, 1028-1037. https://doi.org/10.1111/j.1349-7006.2012.02260.x

100. Wu, Y., Wu, P., Zhang, Q., Chen, W., Liu, X., Zheng, W., 2019. MFAP5 promotes basallike breast cancer progression by activating the EMT program. Cell Biosci. 9, 24. https://doi.org/10.1186/s13578-019-0284-0

101. Wuttig, D., Zastrow, S., Füssel, S., Toma, M., Meinhardt, M., Kalman, K., Junker, K., Sanjmyatav, J., Boll, K., Hackermüller, J., Rolle, A., Grimm, M.-O., Wirth, M., 2012. CD31, EDNRB and TSPAN7 are promising prognostic markers in clear-cell renal cell carcinoma revealed by genome-wide expression analyses of primary tumors and metastases. Int. J. Cancer J. Int. Cancer 131, E693-704. https://doi.org/10.1002/ijc.27419

102. Xu, B., Li, J., Liu, X., Li, C., Chang, X., 2017. TXNDC5 is a cervical tumor susceptibility gene that stimulates cell migration, vasculogenic mimicry and angiogenesis by down-regulating SERPINF1 and TRAF1 expression. Oncotarget 8, 91009-91024. https://doi.org/10.18632/oncotarget.18857

103. Xu, C., Wu, X., Zhu, J., 2013. VEGF Promotes Proliferation of Human Glioblastoma Multiforme Stem-Like Cells through VEGF Receptor 2 [WWW Document]. Sci. World J. https://doi.org/10.1155/2013/417413

104. Xu, S., Liu, Y., Meng, Q., Wang, B., 2018. Rab34 small GTPase is required for Hedgehog signaling and an early step of ciliary vesicle formation in mouse. J. Cell Sci. 131. https://doi.org/10.1242/jcs. 213710

105. Yan, D.-W., Fan, J.-W., Yu, Z., Li, M., Wen, Y.-G., Li, D.-W., Zhou, C.-Z., Wang, X.L., Wang, Q., Tang, H.-M., Peng, Z.-H., 2012. Downregulation of Metallothionein 1F, a putative oncosuppressor, by loss of heterozygosity in colon cancer tissue. Biochim. 
Biophys. Acta BBA - Mol. Basis Dis. 1822, 918-926.

https://doi.org/10.1016/j.bbadis.2012.02.021

106. Yang, S., Gao, K., Li, W., 2019. Identification of hub genes and pathways in glioblastoma by bioinformatics analysis. Oncol. Lett. 17, 1035-1041.

https://doi.org/10.3892/ol.2018.9644

107. Yao, M., Li, S., Wu, X., Diao, S., Zhang, G., He, H., Bian, L., Lu, Y., 2018. Cellular origin of glioblastoma and its implication in precision therapy. Cell. Mol. Immunol. 15, 737-739. https://doi.org/10.1038/cmi.2017.159

108. Ye, X., Xu, S., Xin, Y., Yu, S., Ping, Y., Chen, L., Xiao, H., Wang, B., Yi, L., Wang, Q., Jiang, X., Yang, L., Zhang, P., Qian, C., Cui, Y., Zhang, X., Bian, X., 2012. TumorAssociated Microglia/Macrophages Enhance the Invasion of Glioma Stem-like Cells via TGF- $\beta 1$ Signaling Pathway. J. Immunol. 189, 444-453.

https://doi.org/10.4049/jimmunol.1103248

109. You, J.-J., Lin-Chao, S., 2010. Gas7 Functions with N-WASP to Regulate the Neurite Outgrowth of Hippocampal Neurons*,. J. Biol. Chem. 285, 11652-11666. https://doi.org/10.1074/jbc.M109.051094

110. Yu, H., Ding, J., Zhu, H., Jing, Y., Zhou, H., Tian, H., Tang, K., Wang, G., Wang, X., 2020. LOXL1 confers antiapoptosis and promotes gliomagenesis through stabilizing BAG2. Cell Death Differ. 27, 3021-3036. https://doi.org/10.1038/s41418-020-0558-4

111. Yu, M., Xue, Y., Zheng, J., Liu, X., Yu, H., Liu, L., Li, Z., Liu, Y., 2017. Linc00152 promotes malignant progression of glioma stem cells by regulating miR-103a3p/FEZF1/CDC25A pathway. Mol. Cancer 16, 110. https://doi.org/10.1186/s12943-0170677-9

112. Yu, M., Yu, S., Xue, Y., Yu, H., Chen, D., Wei, X., Liu, Y., 2018. Over-Expressed FEZF1 Predicts a Poor Prognosis in Glioma and Promotes Glioma Cell Malignant Biological Properties by Regulating Akt-ERK Pathway. J. Mol. Neurosci. MN 65, 411419. https://doi.org/10.1007/s12031-018-1108-0

113. Yu, X., Zhai, C., Fan, Y., Zhang, J., Liang, N., Liu, F., Cao, L., Wang, J., Du, J., 2017. TUSC3: a novel tumour suppressor gene and its functional implications. J. Cell. Mol. Med. 21, 1711-1718. https://doi.org/10.1111/jcmm.13128 
114. Yuan, J., Yu, X., Wang, A., Li, Y., Liu, F., Wang, Y., Sun, S., Bing, X., Liu, Y., Du, J., 2018. Tumor suppressor candidate 3: A novel grading tool and predictor of clinical malignancy in human gliomas. Oncol. Lett. 15, 5655-5661. https://doi.org/10.3892/ol.2018.8082

115.Zhang, H., Xiong, Y., Xia, R., Wei, C., Shi, X., Nie, F., 2017. The pseudogene-derived long noncoding RNA SFTA1P is down-regulated and suppresses cell migration and invasion in lung adenocarcinoma. Tumor Biol. 39, 1010428317691418. https://doi.org/10.1177/1010428317691418

116. Zhang, P., Xia, Q., Liu, L., Li, S., Dong, L., 2020. Current Opinion on Molecular Characterization for GBM Classification in Guiding Clinical Diagnosis, Prognosis, and Therapy. Front. Mol. Biosci. 7, 562798. https://doi.org/10.3389/fmolb.2020.562798

117.Zhang, R., Xu, T., Xia, Y., Wang, Z., Li, X., Chen, W., 2021. ITM2A as a Tumor Suppressor and Its Correlation With PD-L1 in Breast Cancer. Front. Oncol. 10. https://doi.org/10.3389/fonc.2020.581733

118. Zhang, S., Peng, J., Guo, Y., Javidiparsijani, S., Wang, G., Wang, Y., Liu, H., Liu, J., Luo, J., 2014. Matrilin-2 Is a Widely Distributed Extracellular Matrix Protein and a Potential Biomarker in the Early Stage of Osteoarthritis in Articular Cartilage [WWW Document]. BioMed Res. Int. https://doi.org/10.1155/2014/986127

119.Zhao, Y., Carter, R., Natarajan, S., Varn, F.S., Compton, D.A., Gawad, C., Cheng, C., Godek, K.M., 2019. Single-cell RNA sequencing reveals the impact of chromosomal instability on glioblastoma cancer stem cells. BMC Med. Genomics 12, 79. https://doi.org/10.1186/s12920-019-0532-5

120.Zheng, P., Zhang, H., Gao, H., Sun, J., Li, J., Zhang, X., Gao, L., Ma, P., Li, S., 2020. Plasma Exosomal Long Noncoding RNA lnc-SLC2A12-10:1 as a Novel Diagnostic Biomarker for Gastric Cancer. OncoTargets Ther. 13, 4009-4018. https://doi.org/10.2147/OTT.S253600 